\title{
IMPLEMENTASI ALGORITMA NAIVE BAYES DALAM PENENTUAN PEMBERIAN KREDIT
}

\author{
Muhammad Husni Rifqo ${ }^{1}$, Ardi Wijaya ${ }^{2}$ \\ ${ }^{1,2}$ Program Studi Informatika, Fakultas Teknik, Universitas Muhammadiyah Bengkulu \\ Jl. Bali PO BOX 118. Telp (0736) 227665, Fax (0736) 26161, Bengkulu 38119 \\ ${ }^{1}$ kokoahzani@gmail.com \\ ${ }^{2}$ Ardi_wijaya18@yahoo.co.id
}

\begin{abstract}
Abstrak: Pengajuan aplikasi kredit oleh calon nasabah sekarang sangatlah mudah, hal ini dikarenakan pengajuan kredit bisa dilakukan semua orang sepanjang memenuhi syarat tertentu. Pemberian kredit kepada nasabah adalah kegiatan rutin yang mempunyai risiko tinggi, hal ini bisa menyebabkan kerugian pada perusahaan dan mengakibatkan kredit macet. Persaingan perusahaan penyedia kredit menjadi sangat pesat dan prediksi konsumen kredit adalah hal yang sangat penting. Analisis terhadap data kredit diperlukan dengan tujuan untuk meminimalisasi risiko nasabah yang terlambat membayar kredit, kegiatan ini sangatlah penting karena salah satu penyebab terjadinya kredit macet bisa disebabkan oleh kurang cermatnya perusahaan dalam pemberian kredit. Masalah ini sebenarnya dapat diatasi dengan cara mengidentifikasi dan memprediksi nasabah dengan baik sebelum memberikan pinjaman dengan cara memperahitkan data historis pinjaman. Teknik prediksi dalam pengambilan keputusan telah banyak digunakan oleh perusahaan-perusahaan besar. Penelitian ini menerapkan algoritma naive bayes untuk memprediksi dan mengklasifikasi nasabah mana saja yang bermasalah dan tidak bermasalah, dan diharapkan mampu meningkatkan akurasi dalam menganalisa kelayakan kredit.
\end{abstract}

Kata kunci : Analisa kredit, penilaian kredit, naive bayes.

Abstract: Submission of a credit application by the prospective customer now is very simple, it is because the credit application can do all of the people all meet certain requirements. Giving credit to customers is routine at high risk, it can cause harm to the company and lead to bad credit. Competition finance providers become very rapid and prediction of consumer credit is very important. An analysis of the credit data necessary for the purpose of minimizing the risk of customers who pay late on credit, this activity is very important because one of the causes of bad loans could be caused by less conscientious companies in the provision of credit. This problem can actually be solved by identifying and predicting customers with good before granting a loan by way of historical data memperahitkan loans. A prediction technique in decision making has been widely used by large companies.This research applies Naive Bayes algorithm to predict and classify the customer anywhere problematic and is not problematic, and is expected to improve the accuracy in analyzing credit worthiness.

Keywords : Credit analysis, credit ratings, naive Bayes.

\section{PENDAHULUAN}

Pada saat ini kegiatan kredit sangatlah ramai, hal ini tampak pada berkembang pesatnya perusahaan-perusahaan yang menawarkan jasa pembiayaan bagi calon nasabah dalam memenuhi suatu kebutuhannya. Sewa guna usaha (leasing) atau sering disingkat SGU adalah kegiatan pembiayaan dalam bentuk penyediaan barang modal baik secara sewa guna usaha dengan hak opsi (finance lease) maupun sewa guna usaha (lessee) selama jangka waktu tertentu berdasarkan pembayaran secara angsuran [1].

Banyak perusahaan menawarkan kredit bagi para nasabahnya, pengajuan kredit bisa diajukan oleh pemohon dengan memenuhi semua persyaratan yang sudah ditentukan oleh perusahaan. Pemberian kredit kepada nasabah 
Jurnal Pseudocode, Volume IV Nomor 2, September 2017, ISSN 2355-5920

www.ejournal.unib.ac.id/index.php/pseudocode

adalah kegiatan rutin yang mempunyai risiko tinggi

[2], hal ini bisa menyebabkan kerugian pada perusahaan dan mengakibatkan kredit macet. Analisis terhadap data kredit diperlukan dengan tujuan untuk meminimalisasi risiko nasabah yang terlambat membayar kredit [3].

Astra Credit Companies (ACC) adalah salah satu perusahaan pembiayaan mobil terbesar di Indonesia. Perusahaan ini menyediakan pelayanan pembiayaan untuk pembelian mobil baru ataupun mobil bekas khususnya untuk merek kendaraan yang diproduksi oleh Astra. Sebagai salah satu perusahaan yang bergerak dalam bidang sewa guna usaha (leasing) ACC juga mengalami kendala dan hambatan dalam hal perkreditan, pemberian kredit sangatlah berisiko karena dari sekian banyak nasabah yang mengajukan aplikasi kredit ada kemungkinan beberapa pelanggan yang bermasalah dalam pembayaran.

Analisa kredit sangatlah penting, salah satu penyebab terjadinya kredit macet bisa disebabkan oleh kurang cermatnya perusahaan dalam pemberian kredit. Masalah ini sebenarnya dapat diatasi dengan cara mengidentifikasi dan memprediksi nasabah dengan baik sebelum memberikan pinjaman dengan cara memperahitkan data historis pinjaman [4]. Teknik prediksi dalam pengambilan keputusan telah banyak digunakan oleh perusahaan-perusahaan besar.

Banyak penelitian yang dilakukan untuk permasalahan risiko kredit dengan menggunakan bermacam metode data mining seperti: Fuzzy Decision Tree, Logistic Regression, Naive Bayes, C4.5, Super Vevtor Machine (SVM) dan metode lain, metode itu dipilih sesuai dengan dataset dan tujuannya. Setiap metode ini mempunyai kelebihan masing-masing sesuai dengan fungsi dan data yang digunakan.
Data mining adalah kegiatan yang meliputi pengumpulan, pemakaian data historis untuk menemukan keteraturan pola dan hubungan dalam set data berukuran besar [5]. Sedangkan menurut Larose [6] data mining adalah proses menelusuri pengetahuan baru, pola dan tren yang dipilah dari jumlah data yang besar yang disimpan dalam repositori atau tempat penyimpanan dengan menggunakan teknik pengenalan pola serta statistik dan teknik matematika.

Data mining merupakan bagian dari proses Knowledge Discovery from Data (KDD). Dibawah ini adalah proses dari KDD:

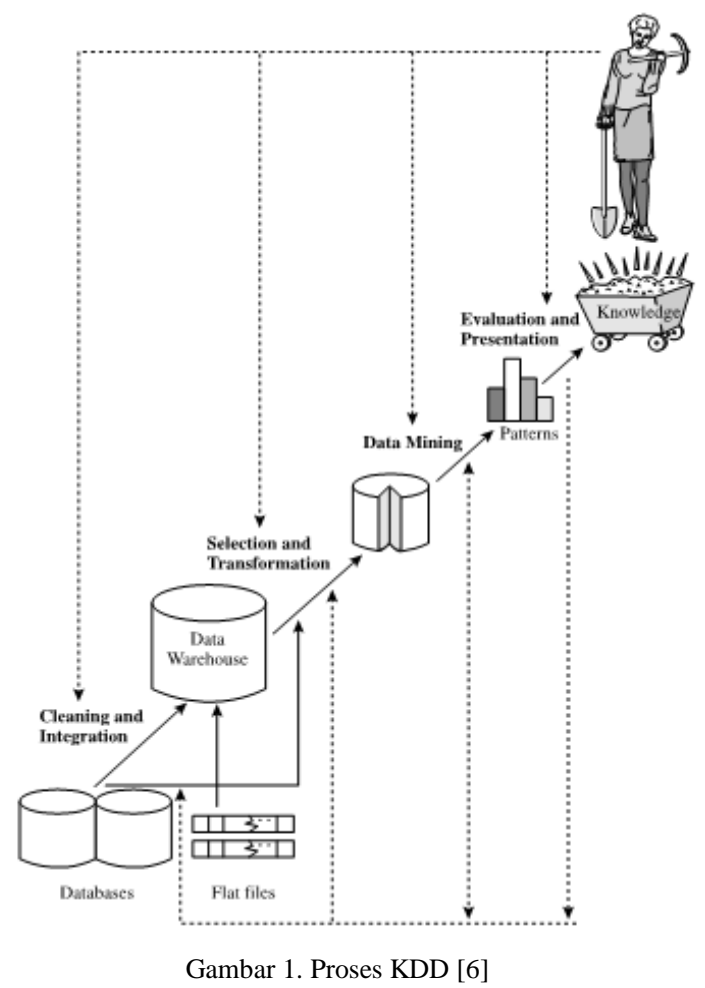

Manajemen risiko adalah suatu proses untuk mengidentifikasi, mengukur, memantau dan mengendalikan risiko yang timbul serta mengambil langkah-langkah perbaikan yang dapat menyesuaikan risiko pada tingkat yang dapat diterima [7]. Dalam penerapan data mining pada data berskala besar diperlukan metodologi sistematis untuk menganalisis dan mempersiapkan data. Metodologi sistematis juga dibutuhkan untuk 
Jurnal Pseudocode, Volume IV Nomor 2, September 2017, ISSN 2355-5920

www.ejournal.unib.ac.id/index.php/pseudocode

\begin{abstract}
melakukan interpretasi sehingga dapat menghasilkan keputusan yang bermanfaat.

Berdasarkan latar belakang diatas, maka permasalahan yang dirumuskan adalah kurang cermatnya perusahaan dalam menganalisa data calon nasabah dan tidak memaksimalkan pada manajemen risiko dalam pemberian kredit.
\end{abstract}

\section{LANDASAN TEORI}

\section{A. Pengertian Implementasi}

Menurut Kamus Besar Bahasa Indonesia, implementasi adalah pelaksanaan dan penerapan, dimana kedua hal ini bermaksud untuk mencari bentuk tentang hal yang disepakati terlebih dahulu. Implementasi adalah proses untuk memastikan terlaksananya sutu kebujakan dan tercapainya kebijakan tersebut. Tujuan dari implementasi sebuah sistem ialah untuk menyelesaikan desain sistem yang telah disetujui, menguji serta mendokumentasikan program-program dan prosedur sistem yang diperlukan, memastikan bahwa personil yang terlibat dapat mengoperasikan sistem yang baru dan memastikan bahwa konversi sistem lama ke sistem baru dapat berjalan dengan baik dan benar [8].

\section{B. Data Mining}

Data mining adalah proses menelusuri pengetahuan baru, pola dan tren yang dipilah dari jumlah data yang besar yang disimpan dalam repositori atau tempat penyimpanan dengan dan teknik matematika [6]. Data mining menganalisis data menggunakan tool untuk menemukan pola dan aturan dalam himpunan data [9]. Perangkat lunak bertugas untuk menemukan pola dengan mengidentifikasi aturan dan fitur pada data.

Budi Santosa menjelaskan bahwa data mining adalah kegiatan yang meliputi pengumpulan, pemakaian data historis untuk menemukan keteraturan pola dan hubungan dalam set data berukuran besar [5]. Suatu organisasi dapat dibanjiri dengan berbagai macam data, sangatlah tidak berguna data yang terkumpul dan tersimpan jika tidak dimanfaatkan [4].

Berdasarkan tugasnya [6] data mining dikelompokkan menjadi: deskripsi, estimasi, prediksi klasifikasi, clustering dan asosiasi.

\section{Klasifikasi}

Pada penelitian ini metode klasifikasi data mining yang digunakan adalah naive bayes, klasifikasi merupakan bagian algoritma dari data mining. Klasifikasi ini adalah algorimta yang menggunakan data dengan target (class/label) yang berupa nilai kategorikal/nominal. Contoh dari klasifikasi adalah menganalisa apakah seseorang akan membeli komputer atau tidak, dalam data mining klasifikasi dapat menghasilkan sebuah prediksi seperti gambar dibawah ini: 

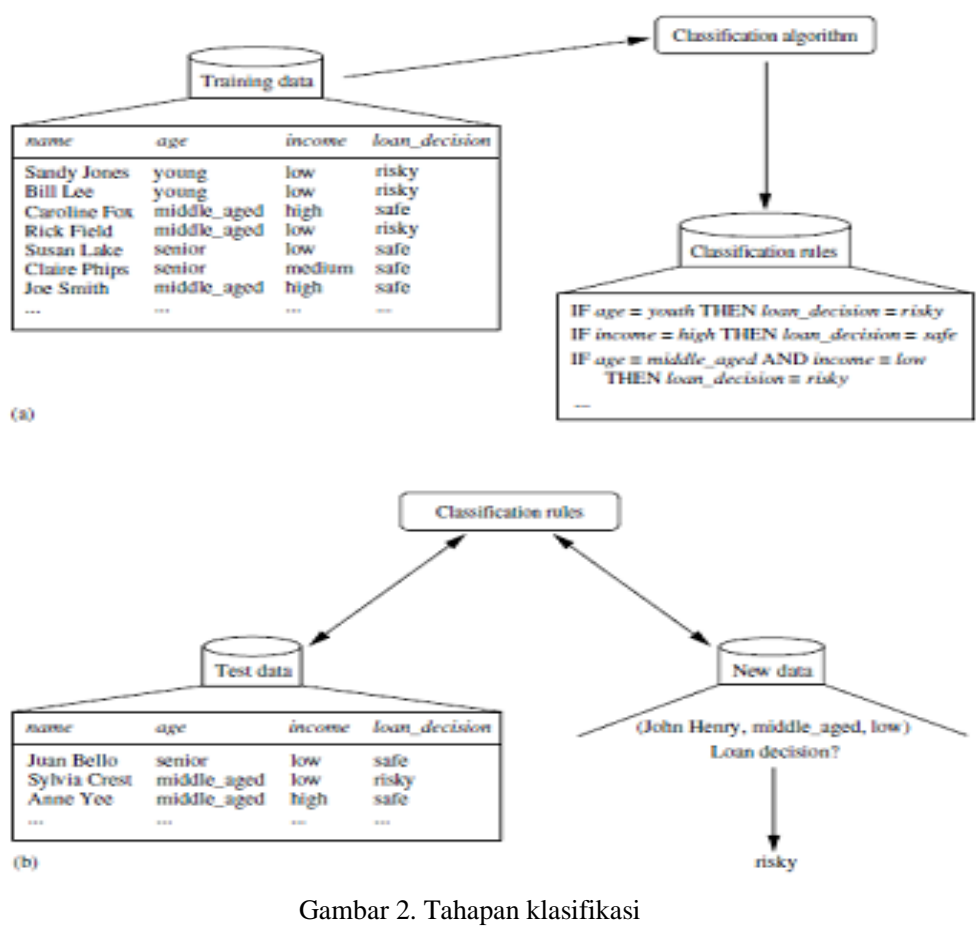

Algoritma klasifikasi yang sering digunakan adalah: naive bayes, KNN, C4.5, ID3, CART dan lain-lain. Dalam penelitian ini peneliti menggunakan algoritma naive bayes.

\section{Algoritma Naive Bayes}

Pengklasifikasi bayesian adalah pengklasifikasi statistik dan didasarkan pada teorema bayes. Teori keputusan bayes [5] adalah pendekatan statistik yang fundamental dalam pengenalan pola (pattern recognition), penggunaan algoritma ini dalam hal klasifikasi harus mempunyai masalah yang bisa dilihat statistiknya. Misalkan $X$ adalah set atribut data dan $h$ kelas variabel dan jika kelas memiliki hubungan dengan atribut maka diperlukan $X$ dan $h$ sebagai variabel acak dan menangkap hubungan peluang $P(h \mid X)$ ini peluang posterior untuk $h$ dan sebaliknya perior $P(h)$.

\section{Naive Bayes Classifier}

Naive Bayes Classifier mengestimasi peluang kelas bersyarat dengan mengasumsikan bahwa atribut adalah independen secara bersyarat yang diberikan dengan label kelas label kelas label kelas y. Asumsi independen bersyarat dapat dinyatakan dalam bentuk:

$P(X \mid Y=y)=\prod_{i=1}^{d} P\left(X_{i} \mid Y=y\right)$

dengan tiap set atribut $X=\left\{X_{1}, X_{2}, \ldots, X_{d}\right\}$ terdiri dari $d$ atribut.

Tahapan algoritma naive bayes:

1. Menyiapkan data training

2. Setiap data dipresentasikan sebagai vektor berdimensi-n yaitu $X=\left(x_{1}, x_{2}, x_{3}, \ldots \ldots . x_{n}\right)$

3. n adalah gambaran dari ukuran yang dibuat di test dari n atribut yaitu $A_{1}, A_{2}, A_{3} \ldots \ldots \ldots \ldots, A_{n}$

4. $\mathrm{M}$ adalah kumpulan kategori yaitu $C_{1}, C_{2}, C_{3}, \ldots \ldots . . C_{m}$

5. Diberikan data test $X$ yang tidak diketahui kategorinya, maka classifier akan memprediksi bahwa $X$ adalah milik kategori dengan posterior probability tertinggi berdasarkan kondisi $X$

6. Naive bayes classifier menandai bahwa test $X$ yang tidak diketahui tadi ke kategori $C_{1}$ jika 
Jurnal Pseudocode, Volume IV Nomor 2, September 2017, ISSN 2355-5920 www.ejournal.unib.ac.id/index.php/pseudocode

dan hanya jika $P\left(C_{i} \mid X\right)>P\left(C_{j} \mid X\right)$ untuk $1 \leq j \leq$ $m, j \neq i$

7. Kemudian kita perlu memaksimalkan $P\left(C_{i} \mid X\right)$ $P\left(C_{i} \mid X\right)=\underline{P\left(X \mid C_{i}\right) \cdot P\left(C_{i}\right)}$ $P(X)$

8. Dimana $\mathrm{x}$ adalah nilai-nilai atribut dalam sampel $X$ dan probabilitas $P\left(x_{1} \mid C_{i}\right)$, $P\left(x_{2} \mid C_{i}\right), \ldots \ldots . P\left(x_{n} \mid C_{i}\right)$, dapat diperkirakan dari data training

\section{a. Sewa Guna Usaha (SGU)}

Menurut Perpres No. 9 Tahun 2009 tentang lembaga pembiayaan [10], sewa guna usaha (leasing) atau sering disebut SGU adalah kegiatan pembiayaan dalam bentuk penyediaan barang modal baik secara sewa guna usaha dengan hak opsi (finance lease) maupun sewa guna usaha (lessee) selama jangka waktu tertentu berdasarkan pembayaran secara angsuran.

Kegiatan leasing mempunyai empat tahap utama:

1. Perjanjian antara pihak lessor dengan pihak lessee.

2. Berdasarkan perjanjian sewa guna usaha, lessor mengalihkan hak penggunaan barang pada pihak lessee.

3. Lessee membayar kepada lessor uang sewa atas penggunaan barang (asset).

4. Lessee mengembalikan barang tersebut pada lessor pada akhir periode yang ditetapkan lebih dahulu dan jangka waktunya kurang dari umur ekonomi barang tersebut.

\section{METODE PENELITIAN}

Proses standar yang harus digunakan dalam data mining adalah CRISP-DM, yang mempunyai tahapan sebagai berikut [6]:

\section{A. Business Understanding}

Tahap pemahaman penelitian, untuk tujuan proyek penelitian dalam perumusan mendefinisikan masalah data mining.

\section{B. Data Understanding}

Tahap pengumpulan data, menganalisa data dan evaluasi kualitas data. Adapun data yang digunakan dalam penelitian ini adalah:

1. Data Agiing kredit perusahaan ACC dari tahun 2010 sampai dengan tahun 2011.

2. Untuk perbandingan akurasi model yang diusulkan maka penelitian ini juga menggunakan public data set yang ada di UCI data set, yaitu data persetujuan kredit (credit approval) negara Japan dan Australia.

\section{Data Preparation}

a. Siapkan data mentah (data set) yang akan digunakan untuk tahap-tahap berikutnya.

b. Pilih variabel yang akan menjadi penentu untuk permasalahan.

c. Lakukan transformasi pada variabel tertentu.

d. Bersihkan data mentah sehingga data siap untuk di analisa.

\section{Tahap Modelling}

a. Pilih model atau teknik yang akan diterapkan.

b. Pengaturan kalibrasi model untuk optimalisasi hasil.

c. Teknik yang berbeda dapat digunakan untuk masalah yang sama.

\section{E. Evaluasi}

Melakukan evaluasi terhadap model untuk mengambil keputusan mengenai pengunaan data mining.

\section{F. Deployment}

Memanfaatkan model yang sudah dibuat serta melaksanakan model untuk proses data mining. 
Jurnal Pseudocode, Volume IV Nomor 2, September 2017, ISSN 2355-5920

www.ejournal.unib.ac.id/index.php/pseudocode

IV. HASIL DAN PEMBAHASAN

\section{A. Pengujian Model}

Penelitian ini bertujuan untuk menguji kekakuratan analisa kredit mobil menggunakan algoritma Naive Bayes. Data yang dianalisa adalah data kredit (Agiing) perusahaan leasing ACC tahun 2010 sampai dengan 2011 dan data yang didapat dari UCI data set, yaitu data persetujuan kredit negara Japan dan Australia.
1. Model Naive Bayes untuk data set Agiing 2010 dan 2011

Algoritma Naive Bayes didasarkan pada teorema Bayes dimana mengukur probabilitas dengan melakukan pendekatan dari suatu ketidak tentuan, gambar di bawah merupakan pengaplikasian model dalam RapidMiner untuk kasus data set Agiing 2010.

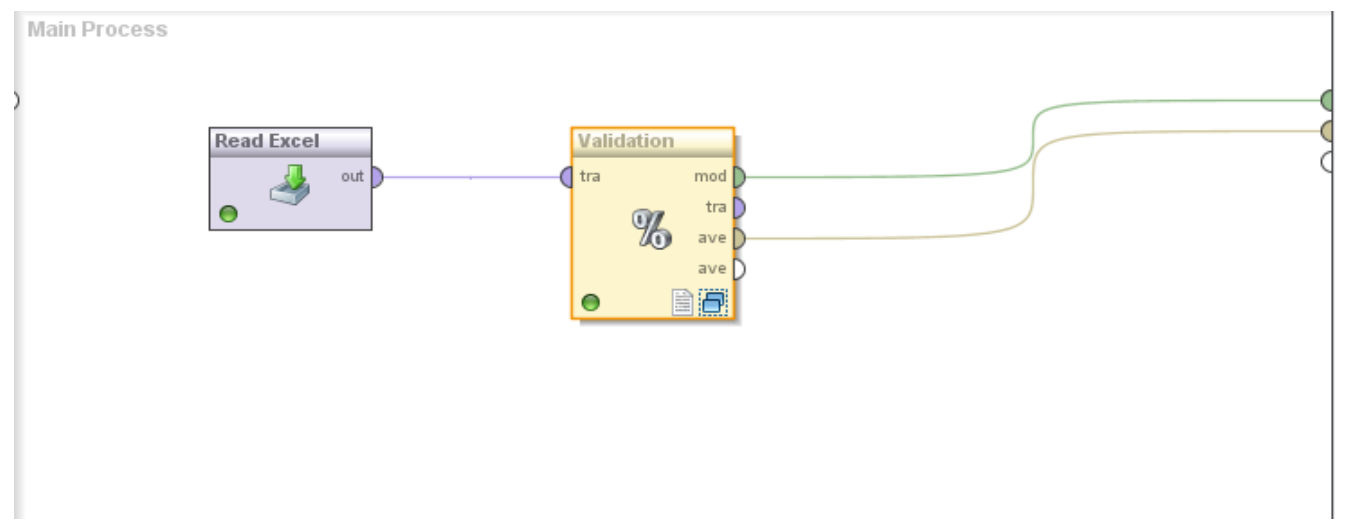

Gambar 3. Model Validation Naive Bayes

Dalam validation terdapat dua kolom: kolom testing dimasukkan apply model dan performance training dan testing. Pada kolom training seperti gambar berikut:.

masukkan model Naive Bayes dan pada kolom

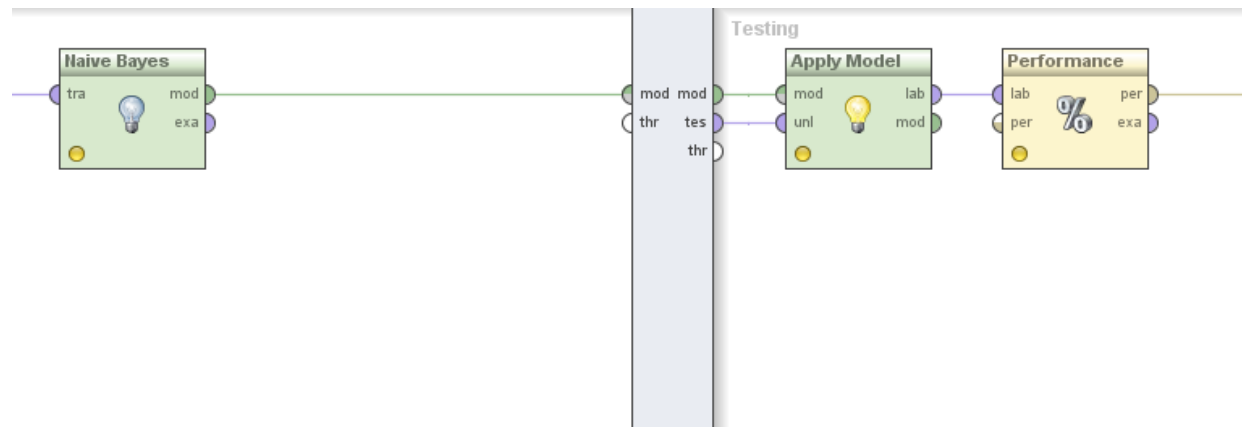

Gambar Error! No text of specified style in document.. Model Naive Bayes, Apply Model dan Performance Algoritma Naive Bayes menghasilkan nilai accuracy $=96,59 \%$, precision $=96,34 \%$ dan recall =99,69\%, seperti gambar dibawah ini:

\begin{tabular}{|c|c|c|c|}
\hline \multicolumn{4}{|c|}{ (-) Table view $\bigcirc$ Plot view } \\
\hline \multicolumn{4}{|c|}{ accuracy: $96.59 \%+j-0.41 \%$ (mikro: $96.59 \%)$} \\
\hline & true BURUK & true BAIK & class precision \\
\hline pred. BURUK & 2025 & 38 & $98.16 \%$ \\
\hline pred. BAIK & 462 & 12143 & $96.33 \%$ \\
\hline class recall & $81.42 \%$ & $99.69 \%$ & \\
\hline \multicolumn{4}{|c|}{ Gambar 5. Accuracy Naive Bayes } \\
\hline
\end{tabular}


Jurnal Pseudocode, Volume IV Nomor 2, September 2017, ISSN 2355-5920

www.ejournal.unib.ac.id/index.php/pseudocode

Gambar di bawah adalah Distribution model pengujian dengan Naive Bayes. Menghasilkan kelas dengan perincian kelas yang baik $=0.170$ dan 16 distribusi, sedangkan kelas buruk mendapatkan hasil $=0.830$ dan 16 distribusi.

\section{SimpleDistribution}

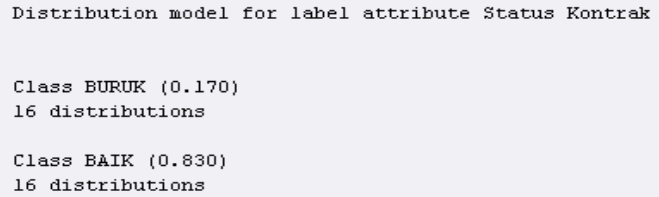

Gambar 6. Distribution mode Naive Bayes

accuracy. $97.59 \%+j-0.51 \%$ (mikro: $97.59 \%$ )

\begin{tabular}{l|l|l|l|}
\hline \hline & true BURUK & true BAIK & class precision \\
\hline pred. BURUK & 1752 & 81 & $95.58 \%$ \\
\hline pred. BAIK & 314 & 14236 & $97.84 \%$ \\
\hline class recall & $84.80 \%$ & $99.43 \%$ & \\
\hline
\end{tabular}

Gambar 7. Accuracy dari Naive Bayes

2. Model Naive Bayes untuk data set Japan dan

Australia Credit Approval

Pada data set ini model Naive Bayes menghasilkan nilai accuracy $=74,89 \%$, precision
Untuk data set Agiing 2011 model Naive Bayes menghasilkan nilai accuracy $=97,59 \%$, precision $=97,84 \%$ dan recall $=99,43 \%$, seperti yang ditunjukkan pada gambar dibawah ini:

\begin{tabular}{|c|c|c|c|}
\hline \multicolumn{4}{|c|}{ accuracy. $74.89 \%+/-3.13 \%$ (mikro: $74.89 \%)$} \\
\hline & true baik & true buruk & class precision \\
\hline pred. baik & 185 & 52 & $78.06 \%$ \\
\hline pred. buruk & 121 & 331 & $73.23 \%$ \\
\hline class recall & $60.46 \%$ & $86.42 \%$ & \\
\hline
\end{tabular}

Sedangkan untuk data set Australia model 80,00\%, precision $=86,47 \%$ dan recall $=65,45 \%$, Naive Bayes menghasilkan nilai accuracy = seperti gambar berikut:

\begin{tabular}{|c|c|c|c|}
\hline \multicolumn{4}{|c|}{ accuracy. $80.00 \%+j-4.93 \%$ (mikro: $80.00 \%$ ) } \\
\hline & true baik & true buruk & class precision \\
\hline pred. baik & 351 & 106 & $76.81 \%$ \\
\hline pred. buruk & 32 & 201 & $86.27 \%$ \\
\hline class recall & $91.64 \%$ & $65.47 \%$ & \\
\hline
\end{tabular}

\section{B. Evaluasi dan validasi model}

Penelitian ini evaluasi dan validasi hasil menggunakan confusion matrix dan ROCcurve.

1. Evaluasi Model Confusion Matrix

Percobaan yang telah dilakukan dengan menggunakan model Naive Bayes sederhana mendapatkan hasil sebagai berikut: 
Jurnal Pseudocode, Volume IV Nomor 2, September 2017, ISSN 2355-5920 www.ejournal.unib.ac.id/index.php/pseudocode

\begin{tabular}{l}
\begin{tabular}{|l|c|c|c|c|c|}
\hline Data set & $\begin{array}{r}\text { Jumlah } \\
\text { record }\end{array}$ & $\begin{array}{c}\text { Jumlah } \\
\text { atribut }\end{array}$ & $\begin{array}{c}\text { Accuracy } \\
(\%)\end{array}$ & $\begin{array}{c}\text { Precision } \\
(\%)\end{array}$ & $\begin{array}{c}\text { Recall } \\
(\%)\end{array}$ \\
\hline $\begin{array}{l}\text { Agiing } \\
2010\end{array}$ & 14668 & 17 & 96,59 & 96,34 & 96,69 \\
\hline $\begin{array}{l}\text { Agiing } \\
2011\end{array}$ & 16383 & 17 & 97,59 & 97,84 & 99,43 \\
\hline $\begin{array}{l}\text { Japan } \\
\text { credit } \\
\text { approval }\end{array}$ & 689 & 16 & 74,89 & 73,40 & 86,46 \\
\hline $\begin{array}{l}\text { Australia } \\
\text { credit } \\
\text { approval }\end{array}$ & 690 & 15 & 80,00 & 86,47 & 65,45 \\
\hline
\end{tabular} \\
\hline
\end{tabular}

2. Kurva Receiver Operating Characteristic (ROC)

Grafik ROC dengan algoritma Naive Bayes untuk data set Agiing 2010 seperti berikut:

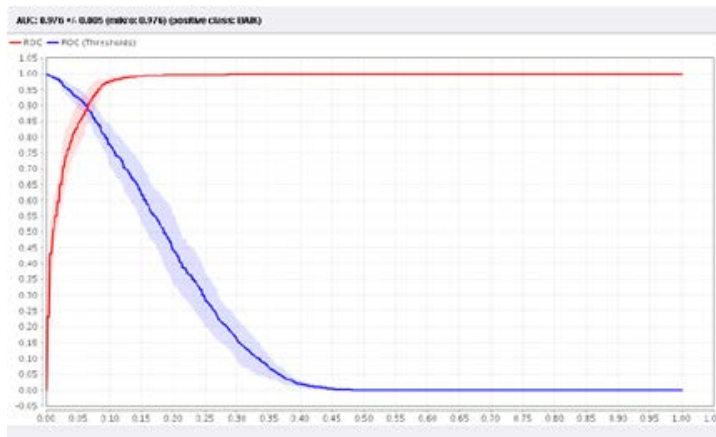

Gambar 10. Grafik ROC dengan algoritma Naive Bayes untuk data set Agiing 2010

Untuk data set Agiing 2011 model Naive Bayes menghasilkan 0,978 seperti yang ditunjukkan pada gambar di bawah ini:

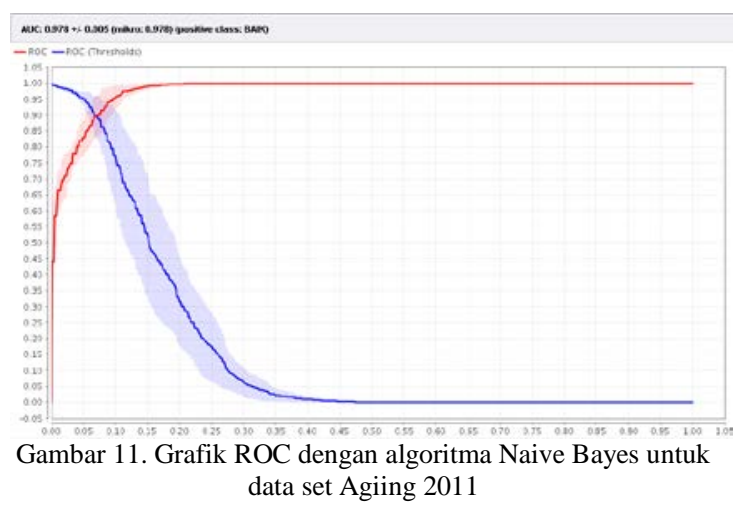

Dan untuk data set Japan credit approval mendapatkan kurva ROC seperti gambar berikut:

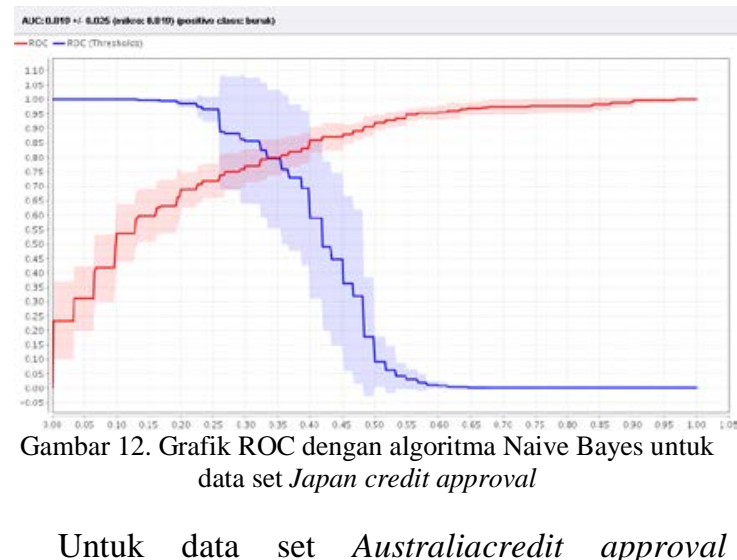

Untuk data set Australiacredit approval mendapatkan kurva ROC seperti gambar berikut:

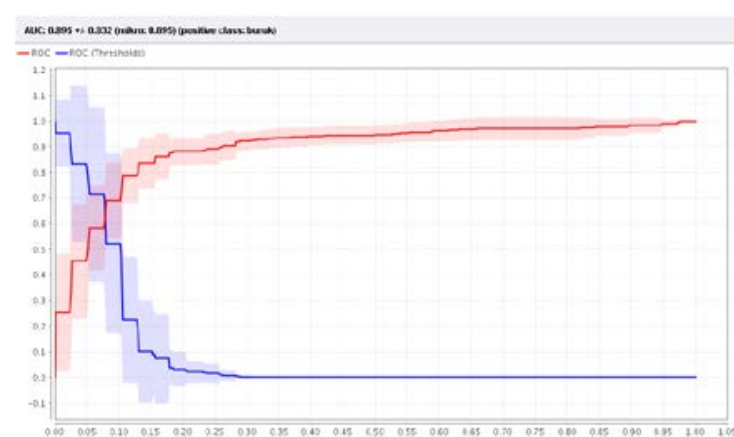

Gambar 13. Grafik ROC dengan algoritma Naive Bayes untuk data set Australia credit approval

\section{Analisa dan Validasi Model}

Hasil dari percobaan menunjukkan bahwa algoritma Naive Bayes mempunyai akurasi yang bagus dalam memprediksi penilaian kredit perusahaan leasing maupun Australia credit approval dan Japan credit approval, seperti yang ditunjukkan pada tabel di bawah ini:

\begin{tabular}{|l|c|}
\multicolumn{1}{|c|}{ Tabel 2. Analisa dan Validasi (accuracy) } \\
\hline Data set & $\begin{array}{c}\text { Algoritma Naive } \\
\text { Bayes (accuracy) }\end{array}$ \\
\hline Agiing 2010 & 96,59 \\
\hline Agiing 2011 & 97,59 \\
\hline Japan credit approval & 74,89 \\
\hline Australia credit approval & 80,00 \\
\hline
\end{tabular}

\section{PENUTUP}

Dari hasil penelitian terbukti bahwa model Naive Bayes mempunyai akurasi yang baik,. hal ini tampak dari hasil evaluasi penelitian bahwa model Naive Bayes mampu menganalisa pelanggan yang baik dan pelanggan yang buruk baik menggunakan 
Jurnal Pseudocode, Volume IV Nomor 2, September 2017, ISSN 2355-5920

www.ejournal.unib.ac.id/index.php/pseudocode

data Agiing leasing ACC maupun menggunakan

data credit approval negara Australia dan Japan

dari UCI data set dengan tingkat akurasi yang baik.

Banyaknya record dan atribut pada sebuah data set mempengaruhi tingkat akurasi dari model Naive

Bayes ini.

\section{REFERENSI}

[1] Peraturan Presiden No 9. 2009.

[2] Penerapan Naive Bayes Untuk Prediksi Kelayakan Kredit. Kurniawan, Dedy Ahmad dan Kriestanto, Danny. 2016, Jurnal Informatika dan Komputer (JIKO), Vol. 1, hal. 19-23.

[3] Analisis Data Pembayaran Kredit Nasabah Bank Menggunakan Metode Data Mining. Melissa, Ira dan S. Oetama, Raymond. 2013, ULTIMA InfoSys, Vol. IV. No1, hal. 18-27.

[4] Aplikasi Data Mining Untuk Penilaian Kredit Menggunankan Metode Fuzzy Decision Tree. Wahyuningtyas, Grizelda, Mukhlash, Imam dan Soetrisno. 2014, JURNAL SAINS DAN SENI POMITS, Vol. 2, No.1, hal. 1-5.

[5] Santosa, Budi. Data Mining Teknik Pemanfaatan Data untuk Keperluan Bisnis. Yogyakarta : Graha Ilmu, 2007.

[6] Larose, Daniel T. Data Mining Methods and Models. Canada : A Jhon Willey \& Sons, Inc.,Publication, 2005.

[7] Analisis Terhadap Penerapan Manajemen Risiko Kredit pada PT. Bank Ekspor Indonesia. Setiawan, Dharma. 2007, hal. 1-19.

[8] Desain dan Implementasi Sistem Informasi Perpustakaan Berbasis Web dengan MVC (Model View Controller). Pertiwi, Dini Hari. 2011, Jurnal Teknologi dan Informatika (Teknomatika), Vol. 1 No.2, hal. 125-147.

[9] Evaluasi Algoritma Untuk Klasifikasi Nasabah Kredit Bank " $X$ " Menggunakan Beberapa Algoritma Klasifikasi. Marcos, Hendra dan Hidayah, Indriana. 2014, Seminar Nasional Teknologi Informasi dan Multimedia ISSN : 2302-3805, Vol. 2.02, hal. 31-36.

[10] Peraturan Presiden Nomor 9. Jakarta : s.n., 2009. 